\title{
Imagined Futures: Young men's talk about fatherhood and domestic life
}

As we move towards the end of the 1990s both popular and academic interest in issues to do with men and masculinity shows no signs of abating. Every year sees the publication of a string of new titles spanning across areas as diverse as anthropology (Cornwall \& Lindesfarne, 1994), psychology (Scher et al, 1993), sociology (Connell, 1995), linguistics (Johnson and Meinhof, 1997) and cultural studies (Berger et al, 1995). One of the main reasons behind this sustained period of interest is the assumption that men are currently in a period of crisis (although see Kimmel, 1987) and that, as a consequence, they are beginning to change. The concepts of the New Man and the New Lad have become cultural common-places (Billig, 1987), littering both media texts and everyday conversations. According to these representations, the New Man (at least) is supposed to differ from his more traditional counter-part in a number of important ways. Whereas the Traditional male is held to be tough, competitive and emotionally inarticulate, the New Man is supposed to represent a softer, more sensitive and caring individual. He is the ideal partner for the modern, liberated woman - attentive in the bedroom, competent in the kitchen and more than willing to pull his weight when it comes to routine domestic chores. The New Father (Lewis, 1986; Lewis and O'Brien, 1987) also departs from the example of his patriarchal predecessor. He not only accompanies his partner during labour, but also sits down with her beforehand to work out their birthplan. He's keen to master the art of nappy changing, enthusiastic when it comes to bottle feeding and burping, and happy to walk around town all afternoon with the child strapped to his chest. 
Unsurprisingly, perhaps, much of the debate about New Men and New Fathers has focused upon the question of whether or not they really exist, with most academic commentators appearing sceptical. The New Man has been variously written off either as a myth (Chapman, 1988), a marketing device (Mort, 1988), or just the latest edition in a long line of hegemonic male identities (Hondagneu-Sotelo and Messner, 1994). However, one of the main problems with these debates is that they serve to reify men, turning them into different types or categories of being. We are encouraged to see men as either New or 'Retributive' (Rutherford, 1988) and as 'traditional', 'good', or 'new' fathers (Pleck, 1987; Russell, 1983; see also Backett, 1987). Yet it is much more useful to see these descriptions as competing cultural ideals; that is, as so many different arguments about how men and fathers should be.

The kind of approach adopted in this article is informed by the concepts and claims of discourse theory and the study of rhetoric developing within social psychology (c.f. Antaki, 1994; Billig, 1987; 1991; Burman and Parker, 1993; Edwards, 1997; Edwards and Potter, 1992; Potter and Wetherell, 1987; Potter, 1996; Parker, 1992; Wetherell and Potter, 1992). More specifically, the analysis is grounded in that strand of discourse theory which pays attention to the more global patterns in collective sense-making and which deploys concepts such as 'interpretative repertoires' (Potter and Wetherell, 1987; Wetherell and Potter, 1988), 'cultural narratives' (Freeman, 1993) and 'subject positions' (Davies and Harré, 1990; Wetherell in press). In common with much discursive psychology (Edwards and Potter, 1992), our work focuses upon the ways that speakers construct different accounts or versions of the world (including themselves) as they move across various interactional settings. It sees identity as something that is actively accomplished within 
particular rhetorical or micro-political contexts (see also Edley, 1993; Harré, 1993; Henriques et al, 1984; Potter and Wetherell, 1987; Shotter and Gergen, 1989 and Widdicombe and Wooffitt, 1995). Unlike some of the more conversation analytic forms of discourse research, however, we also want to emphasize the point that the social world is not constituted $a b$ initio in every conversation. We want to acknowledge that some mobilisations of discourse become more stable and pervasive than others, both at an individual and cultural level. Society provides us with a set of ready-made resources with which to think and talk about the world. It supplies us with a set of 'winning arguments' which make up our common sense (Gramsci, 1971) of understanding. The way that we see the world is not so much determined as guided by this common sense. As commensurate with a constructionist metaphor, it supplies the raw materials with which people can build their accounts.

For us, this two-sided approach to discourse analytical work best captures the paradoxical relationship that exists between discourse and the speaking subject. It allows us to embrace the fact that people are both the products and the producers of discourse; the masters and the slaves of language (Barthes, 1982; Billig , 1991). Within the context of this study, such an approach enables us to see how the fragmented, inconsistent and contradictory nature of our shared cultural knowledge about masculinity and fatherhood comes to structure the everyday lives of a particular group of young men. It allows us to appreciate how men's lives, thoughts and experiences are organized around a particular set of 'ideological dilemmas' (Billig, et al, 1988). Furthermore, in examining their attempts to manage these dilemmas, we should also see moments when this stock of shared understandings is transformed. That is, we should be able to see where common sense itself becomes a site of cultural contestation. 


\section{The Study}

The data analysed in this paper come from a relatively large-scale project on the construction of masculine identities (Edley and Wetherell, 1995; 1996; 1997; Wetherell and Edley, 1998). Part of this project involved an intensive reflexive ethnography (Atkinson, 1989) conducted in and around the sixth form common room of a UK-based independent boys' school which included tape-recorded and transcribed interviews with small groups of white 17-18 year old male students. Each group of three young men was interviewed (by Nigel Edley) around eight times over a period of approximately three months. All of the meetings, which lasted for around an hour, took place on the school premises and during school hours.

The purpose of this ethnography was to examine the construction of middle class masculine identities in one institutional site. The interviews covered aspects of the young men's daily lives, social relations within the common room, their anticipations of their future working and domestic lives, relationships with young women and with male friends, sexuality, popular culture and feminism and social change. The aim in the interviews was to create an informal atmosphere in which, to a large extent, the participants themselves directed the flow of conversation. The young men involved were volunteers, all of whom have been given pseudonyms in the extracts below. Each extract comes with a "postscript" identifying the group and session from which the material is taken. For example, "(B5)" represents an extract taken from the fifth 
meeting of Group B (see Appendix for a brief note on transcription notation).

The present study consists of an analysis of the material generated in response to a set of questions about the young men's future lives. It begins by attempting to identify some of the interpretative repertoires which pattern their accounts of the ways that their lives might unfold. The analysis also focuses upon the 'identity work' done within these accounts. In other words, it pays attention to how the young men position themselves in relation to the available interpretative repertoires of masculinity. What this analysis gives us is a clear view of gender as an ideological battlefield. We can see the extent to which (broadly feminist) arguments about men and masculinity make up part of the sedimented common sense (Gramsci, 1971) of the post-modern lad, whilst looking too at the construction of certain 'rhetorics' of resistance.

\section{Imagined Futures: Delineating the Dilemma.}

One of the questions posed in the interviews invited the participants to imagine how their adult lives would pan out. As one might expect, a wide variety of different stories emerged. However, amongst this variation there were a number of clear patterns, including the fact that almost all of the young men saw themselves as getting married and having children. The discussions turned to the topic of fatherhood and questions were asked about the kinds of relationships that they hoped to have with their children. Again a broad consensus emerged: a good father was constructed as being highly involved in the care of his offspring. 


\section{Extract 1}

PHIL: I think I'd like to (.) I like to spend (.) I'd love to have kids, you know (.) not personally (.) I'd like to have children (.) not have children (NIGEL: Hmm) erm and I'd like (.) I mean I love kids (.) I think they're great (.) and I would like to spend a lot of time with them (C6)

\section{Extract 2}

NIGEL: Do you think that erm you would treat your sons and daughters differently?

NATHAN: Mm.

NIGEL: How?

NATHAN: From the way my dad has anyway.

NIGEL: Go on

NATHAN: Well I'd actually see them sometimes (laughs) (B8)

\section{Extract 3}

AARON: I was saying (.) I mean you said you (inaudible) saying 'oh the New Man would er (.) want to be caring and be there for the kid' and (.) I mean you (.) I can't remember how you said it but I thought at the time (.) that's how $\underline{\mathrm{I}}$ would want to be with my kids (C6)

As we can see, Phil and Aaron represent their imagined involvement as a source of personal satisfaction and enjoyment. Nathan, on the other hand, produces a somewhat different gloss; here fatherhood is constructed as a matter of parental obligation. This moral theme emerges more clearly in the next series of extracts (i.e. 4 \& 5) when the conversations turned to the topic of how they planned to combine work with child care. The idea that parents might employ others to look after their children was often strenuously resisted. 


\section{Extract 4}

TIM: I was just wondering if both parents could stay at work like and the children could be looked after.

ADRIAN: But then you don't get any relationship between the child and the parents because if the parents go off and drop the kid off at the minder's at half eight in the morning and then come to pick it up at 5 or 6 o'clock at night (.) you've only got like (.) 14 hours together which is shit really isn't it because they don't get any relationship at all between them because when they pick the kid up they go to sleep straight away and they take it home and it just sleeps all night until the morning (A5)

\section{Extract 5}

NIGEL: How would you feel if for instance you married someone who was equally ambitious as you erm (.) about family and looking after the children? PHIL: But you'd never bloody see 'em then (1.0) you'd all be at work NIGEL: But how would you arrange it? Would you pack up your job?

PHIL: Would you get a nanny?

PAUL: A nanny

AARON: Ugghhh!!

PHIL: Crap! Forget it!

NIGEL: You would?

AARON: [bangs table] Jesus Paul!

PAUL: Or grandparents or whatever

AARON: (laughs) This will be $=$

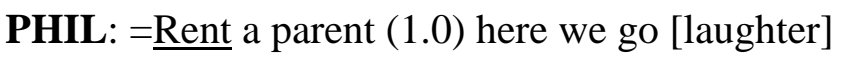

NIGEL: So you'd both sort of continue your erm (.) careers and then you'd get child care?

PAUL: $\mathrm{Hm} \mathrm{m}$

AARON: So someone else is gonna bring up your kid?

PAUL: Well (.) to a certain point.

AARON: $\underline{\text { No }}$ (.) someone else is gonna bring up your kid=

PHIL: =For you (1.0) you're not gonna know the kid.

AARON: You'd go like 'Oh (.) hello (.) you don't know'

PHIL: I've been there (.) you know (.) you don't know the kid at the end of it. AARON: And your kid's gonna resent it (C8) 
However, we should not to lose sight of the fact that these claims were made within the context of arguments. Adrian, Phil and Aaron may well be criticizing those who would pay for child care, but Tim and Paul do not. What is it that allows Tim and Paul to defend such a position? What are the counter-claims that serve to sustain such an argumentative exchange? An important clue emerged later in the same interview (i.e. C8) where Paul suggested that parents could both work and take personal care of the children if one worked conventional hours and the other one nights. In so doing, he acknowledges the importance of 'hands-on' parenting whilst also maintaining the possibility of a career 1 .

The anticipation of entering into paid employment was the other main point of consistency across all of the interviews. As one participant put it, "you just take it for granted I suppose that you'll get a job and get married". A important factor here was the culture of the school, which saw itself as producing the next generation's 'captains of industry'. Accordingly, most of the participants saw themselves following particular career paths, such as businessmen, journalists, teachers and officers in the police and military services. At such points in the interviews a much more traditional discourse of the father-asbreadwinner would sometimes emerge, with its associated themes of 'looking after' and 'providing for' the family. However, as the following two extracts illustrate, the young men typically resisted the interpretation that they were looking for a traditional domestic arrangement.

\section{Extract 6}

TIM: It makes me cringe this role thing does!

NIGEL: Go on (.) tell me.

TIM: I dunno (.) I just don't think it has to be like (.) like so many people have it (1.0) it's an outdated thing (.) I really think it is (.) because (.) why 
can't the father change the nappies and do all the cooking and stuff? (.) or why can't they share it (.) I mean both my parents have always been out to work (.) for as long as I can remember and my dad's done most of the cooking and cleaning and stuff because he always used to get back before my mum (1.0) they were both teachers for quite a long time and (.) if I remember rightly it was my dad that did most of the stuff (.) because my mum used to work most of the day (.) and it hasn't really made any difference (.) it's just the same as it would be the other way round [...] I think it all depends on the situation (1.0) I don't think that the mother should be expected to do such and such and stay at home when the child's young and the father go out to work and work on the car and everything (.) but it could be that way (.) it depends on the situation that the family's in but it shouldn't be expected of everybody because then a few people feel pressured into roles and stuff (A5)

\section{Extract 7}

AARON: I could see myself slipping into the role where I bring in all the money and she'd be wor (.) she'd be not working at home (.) but it would have to be a mutual thing I mean (.) I don't want like to stick her at home and say "Right (.) I'm getting the cash (.) you stay 'ere and look after sprout" NIGEL: Right (.) yeah (.) I mean that (.) that's the point (.) would you be sort of happy with what in the end turns out to be erm (.) a traditional family arrangement?

AARON: I'd be happy (.) I'd be alright with it as long as my spouse was alright with it (.) if she didn't see herself as being used or dominated over or er (.) just being stuck in the role because it's socially accepted then (.) and it was like she's doing it because she wants to (.) then I'd be alright with that (C6)

There is ample evidence of liberal feminist themes within these two accounts. The modern man is seen as no longer the (automatic) head of the household. The commanding male voice is constructed as foreign or 'Other'. Significantly, here it is presented as a voice of the industrial North or working classes ${ }^{2}$, a voice from the past. Aaron constructs himself as having neither the individual authority nor the will to tell his partner what to do. Theirs would be a mutual, egalitarian relationship. And yet clearly the appeal of the traditional male role is still strong, with 
its guarantees of power and status. It encourages Aaron to imagine a scenario in which his partner willingly accepts a situation that feminists for a long time now have characterized as patriarchal (eg. Delphy, 1984; O'Brien, 1981). Nevertheless, Aaron can be seen to be trying to find a 'solution' to a powerful ideological dilemma: he wants to have children and he'd like to be there for them, but he also wants to pursue a career; he wants an egalitarian relationship with his partner, but at the same time would prefer her to stay at home with the kids. In a sense, these young men are the battleground upon which the war between cultural ideals is raging. The dominant understandings of what it means to be a man/father depends upon how they position themselves (and justify those positions) within this ideological field. Consequently, in the second part of this paper we want to look at some of the ways in which those battles are played out. More specifically, we will be considering just three of the broad strategies through which the above dilemma is managed.

\section{Strategy One: Back to Basics.}

To some extent at least, the legitimacy of the New Father as a cultural ideal rests upon the assumption that it makes little or no difference who looks after the kids. As long as they develop stable and loving relations with their children, it is argued that the primary caretaker can be either the mother or the father. This, of course, challenges a long standing belief that women are better suited to the parenting role. Part of this argument centred around the assumption that women possessed a number of key qualities that were important in child care, such as intuition, empathy and a willingness to self sacrifice. Yet more important, perhaps, was the belief that women were physically designed for child care. The 
first device for managing the above ideological dilemma consists of resurrecting this 'older' common sense in order to justify why, in the end, it would be better if the mother looked after the kids.

\section{Extract 8}

ADRIAN: I think that the mother is more of the (.) has a better relationship with the child when the child is younger because she's with the child all the time and er

TIM: But it doesn't have to be like that.

ADRIAN: I know but (.) they've gotta be for a while haven't they?

TIM: Yeah (.) but it is (.) but it doesn't have to be=

ADRIAN: =I mean she's the one that carries the kid around for nine months before she has it (A5)

\section{Extract 9}

AARON: I'm all for everyone having jobs (.) males and females getting the same jobs and all that (NIGEL: Hm m) but someone has (.) I think (.) one person has to be home with the kids (.) whether it's the male or female it doesn't really matter. (NIGEL: Hm m) But perhaps at the beginning (.) I mean well let's face it (.) the female's built for the job (.) you know what I mean? She's er (.) she's the one who could give it milk or er (.) she's the one who's got to have the child to start with so I think perhaps (.) I don't know whether women agree or disagree (.) that a lass perhaps should be with the child for the first (.) I dunno (.) 6 to 12 months (C6)

\section{Extract 10}

AARON: I think both sexes are equally well suited to raising the child (1.0) (NIGEL: Hm m) as I said there's obviously things women can do that men can't (.) so perhaps it would end up being $51 / 49 \%$ but (.) you know (.) the $1 \%$ would have to be there (.) (NIGEL: Right) thanks to thanks to nature (C6)

It is interesting to note that the initial parts of Aaron's accounts (in both 9 and 10) work as disclaimers (Hewitt and Stokes, 1975). That is, the prefacing statements about believing in the equality of the sexes can be seen as serving to prevent what follows as being interpreted as sexist. A 
number of studies of racist (or "new" racist) discourse have revealed a similar pattern of talk where, say, anti-black sentiments are prefaced by an "I'm not prejudiced, but..." (see Cochrane and Billig, 1984; van Dijk, 1984; Seidel, 1988; Billig et al, 1988; Potter and Wetherell, 1987, 1988; Billig, 1991; Wetherell and Potter, 1992). All the same, it does not take much working out to see the action orientation (Heritage, 1984) of Aaron's account of, say, the "one percent" difference. For even such a small degree of differentiation makes the 'logic' of the mother staying at home to look after the children appear reasonable.

\section{Strategy Two: Dividing theory and practice.}

The need for such disclaimers testifies to the precariousness of the first discursive strategy. It is no simple matter (re)constructing women as being purpose-built for child care, as it risks the charge of sexism. Being a "sexist", like being a racist, is an untenable subject position. It is an identity that is hard to live with. People today will overwhelmingly present themselves as "believers" in sexual and racial equality (Gallup Report, 1983; Billig, 1991). Indeed this notion has become part of our contemporary common sense. A safer strategy, therefore, would be one that allowed the speaker to manage the dilemma without disrupting this liberal ideal. One way of doing this is by separating out the principle of equality from the practice of everyday life.

In a study of final year university students' views on equal opportunities, Wetherell et al (1987) noticed the recurrent use of 'theory/practice' or , 'de jure/de facto' distinctions. As with Extract 9 above, they found that speakers would often begin by asserting an ideal - "Oh I'm a firm believer 
in equal rights" - before going on to say why, in practice, this ideal was unrealistic or unrealisable. The same rhetorical strategy was evident many times within our own interviews. Over and again, the endorsement of liberal ideals was juxtaposed with talk of 'practical considerations', thereby enabling the speaker to defends the status quo whilst deflecting accusations of sexism or bigotry. Consider, for example, the following extract.

\section{Extract 11.}

NIGEL: Okay (.) erm (.) do you two think that a mother who goes out to work and the father who stays at home and looks after the child is a domestic arrangement which is likely to lead to an equally well-adapted child?

CARL: I think so yeah.

ADRIAN: Yeah (.) I don't think there's anything wrong with the woman working and the man staying at home.

CARL: For a while it happened to my step-dad and my mum because my step-dad's a lorry driver and er (.) he started his own business but for a period of 4 months (.) erm he couldn't get a licence so he had to stay at home and my mum worked [away] and it was like that for a while (1.0) well I mean that's a short period of time (.) four months but I don't think you'd have a lot of difference at all really.

ADRIAN: I think that if the man and woman have both got a job and the woman's got the best paid job then a man should leave his job and stay at home (A5)

Here we see both Carl and Adrian expressing unqualified support for the 'no difference' thesis. Not for them the old fashioned or "out-dated" (see Extract 6) view that women are better suited to child care, as far as they are concerned, there is nothing, in theory, preventing them from becoming future house-husbands. In the end, Adrian says, it comes down to a practical issue: whoever brings in the least money should look after the kids. In many ways this is one of the most subtle and powerful examples of this device revealed by our analysis. For unlike some of the 
other versions, this one is in no way apologetic. There is no need here to strike a defensive or regretful tone because, at first sight, the issue of who will go out to work and who will stay at home appears to be in the balance. However, (and here, of course, is the rub) given the fact that women's earnings are, on average, significantly lower than that of men's (Faludi, 1992) it is still very likely that, for any given heterosexual couple, it will be more 'economic' for him to be the breadwinner.

A somewhat modified form of this same practical consideration resurfaced at other points within the interviews. In Extracts 12 and 13, for example, the simple economic calculation of 'whoever has the bigger salary' has been given what Anita Pomerantz (1986) would call an extreme case formulation.

\section{Extract 12}

NIGEL: Would you imagine erm working part-time and looking after your children if you were to have any?

ADRIAN: No I don't think so.

TIM: It depends on your situation.

ADRIAN: Yes

TIM: On her situation and your situation.

ADRIAN: If I had a really crap job and my wife had a really good job and she was getting lots of money (.) then I think it would be more sensible if the wife still went to work and the husband didn't and stayed at home and looked after the children (A1)

\section{Extract 13}

AARON: Erm if (.) I mean it would depend a lot on my situation if I couldn't find a job in whatever field I choose (.) I've got no idea what I'm gonna do yet anyway (NIGEL: Hm m) and my wife or (.) whatever is at the time (laughs) has got a really powerful job bringing in lots of cash (.) well then (.) then I'd slip into the house-husband (C6) 
Extreme case formulations generally work to make a report or account more rhetorically effective through the use of some form of overstatement or exaggeration. Someone might complain, for instance, that I am "always late for appointments", thereby working up or emphasizing the pervasiveness of the problem. In the above extracts, however, the extreme case formulations are used in a slightly different way. The topic under discussion was whether the boys could imagine themselves becoming house-husbands. And, once again, we see them suggesting that it all "depends on the situation". However, this time the situation necessary for him to take over the house-husband role is even more unlikely. No longer is it a simple matter of comparing pay cheques, instead he would have to be in a "really crap" job, or even unemployed, whilst his partner had a "really good" or "really powerful job bringing in lots of cash". Nevertheless, from a rhetorical point of view, what is significant is that insofar as they are still presenting scenarios in which they would take over the domestic role, the young men are defending themselves from the accusation of having ruled such ideas out of court.

In their original study, Wetherell et al (1987) suggested that practical considerations talk is most effective when 'self [is] distanced from the requirements of reality'; that is, when the practicalities undercutting the ideal are out of the speaker's hands. In many ways the above economic argument provides a perfect example of this, for how many people can dictate their own wage-packet, let alone that of their partner? Yet within the present analysis there were a number of other instances where the 'requirements of reality' were firmly bound up with the character or personality of the speaker. Look, for example, at Extract 14. 


\section{Extract 14.}

NIGEL: Erm (.) could any of you imagine sort of really wanting to erm take over the sort of more (.) like the house-husband role?

PHIL: I hate cleaning! (laughs) I can't (.) I mean I'm terrible (.) I really am a messy person (AARON: Yeah) I don't clean my room (.) unless I'm specifically asked 28 times or something like that (.) but then again I wouldn't argue with my partner and say "Look I really want to spend time with my child (.) let me do all the housework and stuff" and all this and besides the fact that I don't particularly fancy the idea of that sort of chore []

NIGEL: Okay so house-husband's not for you (.) what about you two?

PHIL: I'd do it but not unless I was=

PAUL: =I don't think it's something (PHIL: asked to do it) I think I'd want my independence like Phil was (.) I think (.) I'm the same as Phil (.) I'm an untidy person (.) I don't mind doing the cooking but as far as tidying up would go it would be a non-starter

[]

PHIL: You'd do it if you felt it necessary.

AARON: Yeah (.) if you had to you could do it (.) I mean as I say I'm (PHIL: Willingly) I'm completely crap at tidying up as this lot are (NIGEL: Hm m) erm (.) and I could see myself getting irate with the kid if it was like with me all the time (.) I could (C6)

Once again we see a similar de jure/de facto distinction: they would be house-husbands in theory but, in practice, it would not really work as all declare themselves poor housekeepers. What is, of course, so interesting about these accounts is not only that they appeal to a set of interpretative resources about individual character and its fixity (such that it is out of our own hands to change ourselves - see Potter et al, 1984; Wetherell and Potter, 1989; Edley, 1993) but also that they frame the participants as inept or deficient. "I'm completely crap at tidying up" says Aaron. It is as if he wished that he was competent at hoovering and ironing so that he could fulfil the house-husband role. A similar type of construction emerged when the young men spoke about fatherhood. Like most of his 
peers, for example, Aaron talked about wanting to be a highly participant father. However, at the end of the last extract we see him constructing a kind of limit to his involvement. "I could see myself getting irate with the kid if it was like with me all the time" he says. In other words, not only does Aaron invoke another kind of personal failing (i.e. lack of patience) as his excuse for rejecting the house-husband option, but he also implies that the main beneficiary of his more limited involvement would be the child rather than himself.

Strategy Three: Renegotiating the Ideals.

A third way of managing the ideological dilemma as outlined above involves trying to relieve the tension between competing ideals. As it stands, the young men are caught between at least two contradictory subject positions. In a sense, they imagine themselves both as New and Traditional "kinds" of men. However, by renegotiating either one of these ideals they can reduce the apparent conflict. In the following extract we can see at least two distinctive ways of accomplishing this cultural transformation.

\section{Extract 15.}

NIGEL: If a New Man was in a relationship with a family (.) how would they organise their home life?

AARON: He'd do everything but give birth to the kid. (PHIL: No!) I mean there's that talk of men wanting to actually have the child (.) have it implanted next to their erm (.) large intestine (NIGEL: Hm m) or something (.) I think that's completely stupid (.) that's like one end of the scale and (.) not to put too fine a point on it (.) men aren't really designed for that sort of thing (1.0) the kid's got to be sliced out anyway. (NIGEL: Hm m) New man in a (.) I mean 
if it's like the totally stereotypical New Man in a relationship would want to do everything (.) would er (.) I dunno (.) offer to breast feed if he could.

PHIL: No (.) he wouldn't (.) at least I don't think so (1.0) my vision of the New Man wouldn't be so forthright (1.0) I don't think it's right (.) I think (.) it may be quite possibly the New Man is the guy (.) I mean he may go out to work in a suit (.) come home in a suit but wouldn't be work orientated (.) if he had the option (.) you know (.) doing overtime (.) just had a kid (.) you know (.) he'd skip it (.) he'd come home and look after the kid (1.0) on the weekend (.) you know (.) he'd spend a lot of time with his child (.) look after him (.) just give the mother a break (C6)

In the first part of this extract Aaron can be seen as attempting to discredit the ideal of the New Man/ Father. The image he constructs is of someone who is extreme in his desire for equality. Not satisfied with just sharing the post-natal chores of feeding, cleaning and changing, the New Man/ Father, according to Aaron, wants to have the baby as well. Once again Aaron invokes the idea of a natural order - women are designed for childbirth, men are not - the implication being, of course, that anyone who ignores such natural facts should be derided rather than emulated. Phil, on the other hand, constructs a much less negative portrait. Within his version the New Father represents someone who adjusts the balance of his main priorities away from his career and towards his wife and family. Interestingly, the portrait painted here is very similar to the description of the so-called "good father" in Graeme Russell's study (Russell, 1983). The most significant thing about this representation is, of course, that the involvement of the New Man/ Father becomes redefined as a matter of giving the mother a hand. Irrespective of whether he 'helps out' at weekends, or 'takes over' in the evenings, we are left in no doubt that routine domestic chores are her responsibility rather than his. 


\section{Conclusion}

Our first aim in this paper was to develop an outline of the interpretative resources available to a sample of young white middle-class men as they discussed their possible future lives. What became apparent was the way in which their discourse was marked by a number of potentially inconsistent positions. Drawing upon the ideas of Billig et al (1988), we can see that the young men are faced with a complex ideological dilemma - the management of which has important implications for their identities as men. The second part of the paper was dedicated to examining the ways in which the young men attempted to deal with this dilemma. It focused upon how they both employed and also adapted the available interpretative resources in order to justify their imagined futures.

Finally, in referring to these dilemmas as ideological in nature, we are not trying to imply that these young men are peddling some kind of 'false consciousness' or set of 'interested illusions' in contrast to some other hidden truths about the world. Rather, we use it as a reminder that their discursive work is consequential for gender relations and is linked to broader social/discursive practices imbued with power. In his discussion of the conditions for feminist politics, Robert Connell (1995) argues that although huge inequalities and asymmetries are still evident in gendered relations, the legitimation of patriarchy is crumbling in industrial countries. As an illustration he reminds his readers of the words of "a young working-class man with a record of violence and imprisonment, briskly endorsing equal rights for women and complaining about 'prejudiced blokes' who do not" (1995, p. 226). In many respects, our analysis supports this picture, for there is clearly scope here for different arguments and negotiations between young men and women. However, 
we have also tried to demonstrate that precisely because discourse is multi-layered, worked up for occasions and dilemmatic in character, it would be naive to assume that we are witnessing the dawning of a new era of sexual equality. Indeed, there is substantial evidence in our analyses of how liberal feminist themes are recuperated and re-worked into new (albeit more tentative) rhetorics of legitimation. As Connell himself notes, liberal pluralism per se is unlikely to provide a satisfactory basis for progressive change.

\section{Appendix - Transcription Notation}

The following transcription notation represents a simplified version of that developed by Gail Jefferson (see Atkinson and Heritage (1984) for a more comprehensive account).

(.) Short pause of less than 1 second.

(1.0) Timed pause (in seconds).

[...] Material deliberately omitted.

[text] Clarificatory information.

text $\quad$ Word(s) emphasized.

A: no $=\quad$ The end of one speakers' utterance runs straight into

$\mathrm{B}:$ =gap the beginning of the next. 


\section{Notes}

1. Significantly, Paul was attacked here for proposing such a "solution" on the basis that this would give little or no time for the parents to be together. Hence, this adds another dimension to the ideological dilemma faced by these young men.

2. See Hondagneu-Sotelo and Messner (1994) for a discussion of how discourses of the New Man operate within the domain of class politics.

\section{Acknowledgements}

We would like to acknowledge three very different kinds of debt. The first goes to the Economic and Social Research Council (Grant No. R000233129), the Open University and the Faculty of Humanities at Nottingham Trent University for the financial support they have given this research. Secondly, we would like to thank Derek Edwards and Paul Stenner for their constructive criticisms of an earlier draft of this paper. Our final and most important debt of gratitude, however, is extended to the men who took part in this study. Needless to say, without their kindness, co-operation and openness, such work as this would never get done. 


\section{References}

Antaki, C. (1994) Explaining and Arguing: The Social Organisation of Accounts. London: Sage.

Atkinson, P. (1989) The Ethnographic Imagination. London: Routledge.

Atkinson, J.M. and J.C. Heritage (eds) (1984) Structures of Social Action: Studies in Conversation Analysis. Cambridge: Cambridge University Press.

Backett, K. (1987) 'The Negotiation of Fatherhood' in C. Lewis and M. O'Brien (eds.) Reassessing Fatherhood: New Observations on Fathers and the Modern Family, London, Sage.

Barthes, R. (1982) Inaugural lecture, College de France. In S. Sontag (ed.) A Barthes Reader. London: Jonathan Cape.

Berger, M., B. Wallis and S. Watson (eds) (1995) Constructing Masculinity. London: Routledge.

Billig, M. (1987) Arguing and Thinking: A Rhetorical Approach to Social Psychology. Cambridge: Cambridge University Press.

Billig, M. (1991) Ideology and Opinions: Studies in Rhetorical Psychology. London: Sage.

Billig, M., S. Condor, D. Edwards, M. Gane, D. Middleton and A. Radley (1988) Ideological Dilemmas: A Social Psychology of Everyday Thinking. London: Sage.

Burman, E. and Parker, I. (eds.) (1993) Discourse Analytic Research. London: Routledge.

Chapman, R. (1988) 'The Great Pretender: Variations on the New Man Theme' in R. Chapman and J. Rutherford (eds.) Male Order: Unwrapping Masculinity London: Lawrence and Wishart.

Cochrane, R. and M. Billig (1984) 'I'm not National Front, but...', New Society 68: 255-8.

Connell, R.W. (1995) Masculinities. Cambridge: Polity. 
Cornwall, A. and N. Lindisfarne (eds.) (1994) Dislocating Masculinity: Comparative Ethnographies. London: Routledge.

Davies, B. and Harre, R. (1990) 'Positioning: The discursive production of selves'. Journal for the Theory of Social Behaviour', 20 (1), 4363.

Delphy, C. (1984) Close to Home: A Materialist Analysis of Woman's Oppression. London: Hutchinson.

Edley, N. (1993) 'Prince Charles - Our Flexible Friend: accounting for variations in constructions of identity' Text. 13 (3) 397-422.

Edley, N. and M. Wetherell (1995) Men in Perspective: Practice, Power and Identity. Hemel Hempstead: Prentice Hall/Harvester Wheatsheaf.

Edley, N. and M. Wetherell (1996) 'Masculinity, Power and Identity' in M. Mac An Ghaill (ed.) Understanding Masculinities: Social Relations and Cultural Arenas Buckingham: Open University Press.

Edley, N. and M. Wetherell (1997) Jockeying for Position: the construction of masculine identities Discourse and Society 8 (2): 203-17.

Edwards, D. (1997) Discourse and Cognition. London: Sage

Edwards, D. and J. Potter (1992) Discursive Psychology. London: Sage.

Faludi, S. (1992) Backlash: The Undeclared War Against Women. London: Chatto and Windus.

Freeman, M. (1993) Rewriting the Self: History, Memory, Narrative London: Routledge.

Gallup Report (Sept. 1983) Prejudice in Politics pp. 9-14 in Report No. 216.

Gramsci, A. (1971) Selections from Prison Notebooks London: Lawrence and Wishart.

Harré, R. (1993) Social Being. (2nd Ed.) Oxford: Blackwell. 
Henriques, J., W. Hollway, C. Urwin, C. Venn and V. Walkerdine (1984) Changing the Subject: Psychology, social regulation and subjectivity. London: Methuen.

Heritage, J. (1984) Garfinkel and Ethnomethodology Cambridge: Polity.

Hewitt, J.P. and R. Stokes (1975) 'Disclaimers' American Sociological Review, 40: 1-11.

Hondagnu-Sotelo, P. and M.A. Messner (1994) 'Gender Displays and Men's Power' in H. Brod and M. Kaufman (eds) Theorizing Masculinities. London: Sage.

Johnson, S. and U.H. Meinhof (eds) (1997) Language and Masculinity. Oxford: Blackwell.

Kimmel, M.S. (1987) 'The contemporary "crisis" of masculinity in historical perspective' in H. Brod (ed.) The Making of Masculinities. Boston: Allen Unwin.

Lewis, C. (1986) Becoming a Father. Milton Keynes: Open University Press.

Lewis, C. and O'Brien M. (1987) 'Constraints on Fathers: Research, Theory and Clinical Practice', in C. Lewis and M. O'Brien (eds.) Reassessing Fatherhood: New Observations on Fathers and the Modern Family, London, Sage.

Mort, F. (1988) 'Boy's Own: Masculinity, Style and Popular Culture' in R. Chapman and J. Rutherford (eds.) Male Order: Unwrapping Masculinity London: Lawrence and Wishart.

O'Brien, M. (1981) The Politics of Reproduction. London: Routledge and Kegan Paul.

Russell, G. (1983) The Changing Role of Fathers, Milton Keynes, Open University Press.

Rutherford, J. (1988) 'Who's That Man?' in R. Chapman and J. Rutherford (eds.) Male Order: Unwrapping Masculinity London: Lawrence and Wishart.

Parker, I. (1992) Discourse Dynamics: Critical Analysis for Social and Individual Psychology. London: Routledge. 
Pleck, J.H. (1987) 'American Fathering in Historical Perspective' in M.S. Kimmel (ed.) Changing Men: New directions in research on men and masculinity. Newbury Park: Sage.

Pomerantz, A. (1986) Extreme case formulations: a way of legitimizing claims. Human Studies, 9: 219-29.

Potter, J. (1996) 'Attitudes, social respresentations and discursive psychology'. In M. Wetherell (ed.) Identities, Groups and Social Issues. London and Milton Keynes: Sage and Open University.

Potter, J., P. Stringer and M. Wetherell (1984) Social Texts and Context: Literature and Social Psychology. London: Routledge and Kegan Paul.

Potter, J. and M. Wetherell (1987) Discourse and Social Psychology: Beyond attitudes and behaviour London: Sage.

Scher, M., M. Stevens, G. Good and G.A. Eichenfield (eds) (1993) Handbook of Counceling and Psychotherapy with Men. London: Sage.

Seidel, G. (1988) '"We condemn apartheid, BUT..." A discursive analysis of the European Parliament debate on sanctions (July 1986)' Sociological Review.

Shotter, J. and K.J. Gergen (1989) (eds) Texts of Identity. London: Sage.

van Dijk, T.A. (1984) Prejudice and Discourse: An Analysis of Ethnic Prejudice in Cognition and Conversation. Amsterdam: Benjamins.

Wetherell, M. (in press) 'Positioning and Interpretative repertoires: Conversation analysis and post-structuralism in dialogue'. Discourse and Society.

Wetherell, M., H. Stiven, and J. Potter (1987) Unequal egalitarianism: A preliminary study of discourses concerning gender and employment opportunities. British Journal of Social Psychology, 26: 59-71.

Wetherell, M. and Potter, J. (1988) 'Discourse Analysis and the Identification of Interpretative Repertoires'. In C. Antaki (ed.) Analysing Everyday Explanation. London: Sage. 
Wetherell, M. and J. Potter (1989) Narrative characters and accounting for violence. In J. Shotter and K.J. Gergen (eds) Texts of Identity London: Sage.

Wetherell, M. and J. Potter (1992) Mapping the Language of Racism: Discourse and the legitimation of exploitation Harvester Wheatsheaf.

Wetherell, M. and N. Edley (1998) 'Gender Practices: Steps in the Analysis of Men and Masculinities'. In K. Henwood, C. Griffin and A. Phoenix (eds.) Standpoints and Differences: Essays in the Practice of Feminist Psychology. London: Sage.

Widdicombe, S. and R. Wooffitt (1995) The Language of Youth SubCultures: Social Identity in Action. Hemel Hempstead: Harvester Wheatsheaf. 